\title{
DESCRIPTION OF MATHEMATICS LEARNING WITH CHARACTER AT SMPN 5 MANDAI IN MAROS DISTRICT
}

\author{
Nasri Juharia ${ }^{1)}$, Irwan $\mathrm{Akib}^{2)}$, Djadir ${ }^{3)}$ \\ ${ }^{1}$ Mathematics Education Postgraduate Program \\ ${ }^{2,3}$ Universitas Negeri Makassar, Indonesia \\ e-mail: nasrijuharia@gmail.com
}

\begin{abstract}
The study aims at describing teachers' activities based on the aspects of preparation, implementation, and evaluation of learning in Mathematics learning process which affected on students' character building at SMPN 5 Mandai. The type of this study was descriptive research with qualitative approach. The research subjects were 2 Mathematics teachers at SMPN 5 Mandai who applied 2013 curriculum and teachers who applied character education in learning process. Data collecting method of the study were interview, observation, and documentation. The study employed triangulation method by comparing the data obtained through documentation with observation, and observation with interview. The results of the study reveal that (1) teachers' activities based on the aspects of preparation in Mathematics learning process which affected on the students' character building can be seen from syllabus arrangement and lesson plan of teachers, (2) teachers' activities based on the implementation aspect in Mathematics learning process which affected on students' character building are the teachers applied character education started from opening activity, main activity, and closing activity, (3) teachers' activities based on the evaluation aspect in Mathematics learning process which affected on students' character building are through competence of students' attitude aspect, knowledge aspect such as giving daily examination, and skills. Students' development can be acknowledged by teachers and parents as well as by students' themselves. The evaluation of Mathematics learning with character at SMPN 5 Mandai in Maros discrit has been conducted integrated with teaching and learning activity.
\end{abstract}

Keywords: mathematics learning, character building

\section{PENDAHULUAN}

Abad ke-21 membawa perubahan era yang popular dengan sebutan era globalisasi. Dampak globalisasi yang terjadi saat ini membawa masyarakat Indonesia melupakan pendidikan karakter bangsa. Pendidikan karakter bangsa merupakan pondasi bagi suatu bangsa dalam upaya membantu perkembangan jiwa anak-anak baik lahir maupun batin. Pendidikan karkater merupakan proses berkelanjutan dan tidak pernah berakhir selama manusia masih ada di muka bumi ini (Harun, 2013).

Menurut Fitri (Haryati, 2017), pendidikan karakter dapat diintegrasikan dalam pembelajaran pada setiap mata pelajaran. Materi pembelajaran yang berkaitan dengan norma atau nilai-nilai pada setiap mata pelajaran perlu dikembangkan, dieksplisitkan, dikaitkan dengan konteks kehidupan sehari-hari. Karena itu, pembelajaran nilai-nilai karakter seharusnya tidak hanya diberikan pada arah kognitif saja, tetapi menyentuh pada internalisasi dan pengalaman nyata dalam kehidupan peserta didik sehari-hari di sekolah dan di masyarakat. 
Berbicara tentang pendidikan di Indonesia, kita akan dihadapkan sebuah kenyataan yang kurang menyenangkan. Cermin pendidikan di Indonesia masih terlihat buram. Kurang berkualitasnya output pendidikan di Indonesia dapat kita lihat dari kondisi masyarakat Indonesia. Saat ini banyak bermunculan para kaum terpelajar dengan tingkat intelektualnya yang tinggi, akan tetapi rendah dalam hal karakter positif. Banyak kriminalitas di kalangan pelajar, kasus narkoba, tawuran, dan seks bebas merupakan indikator tidak suksesnya pendidikan kita (Ma'unah, 2014).

Oleh karena itu, diperlukan adanya pendidikan karakter sejak awal yaitu sejak kecil. Selain keluarga, lingkungan sekolah dapat menjadi tempat pendidikan yang baik bagi pertumbuhan karakter anak. Segala peristiwa yang terjadi di dalam sekolah semuanya dapat diintegrasikan melalui pendidikan karakter. Pendidikan karkater di sekolah bertujuan untuk membentuk anak tidak hanya unggul dalam intelektual, akan tetapi juga memiliki karakter yang positif.

Tujuan pendidikan karakter dapat tercapai jika seorang guru yang bertindak sebagai pembentuk karakter siswa di lingkungan sekolah mampu menciptakan kegiatan pembelajaran yang efektif. Disebut efektif, jika pembelajaran tersebut mengintegrasikan pendidikan karakter dengan proses belajar mengajar agar dapat mencapai tujuan pembelajaran pada kompetensi sikap, keterampilan dan pengetahuan secara komprehensif.

Menurut Sumarna (Setyowati, 2015) kurikulum 2013 bertujuan agar output siswa dari pendidikan selain memiliki pengetahuan juga memiliki karakter (sikap) dan keterampilan. Dengan harapan yang sangat tinggi bahwa karakter siswa bisa berubah menjadi lebih baik, maka pada tahun 2013 pula kurikulum 2013 mulai diterapkan di sekolah. Penanaman karakter menjadi sangat penting dan bisa dijadikan pedoman pendidikan karakter pada masa mendatang, karena penanaman karakter anak akan berkembang ke sifat-sifat anak selanjutnya setelah dewasa. Hanya saja, hasil dari pendidikan itu membutuhkan waktu beberapa lama.

Kurikulum 2013 menganut pandangan dasar bahwa pengetahuan tidak dapat dipindahkan begitu saja dari guru kepada peserta didik. Peserta didik adalah subjek yang memiliki kemampuan untuk secara aktif mencari, mengolah, mengkonstruksi, dan menggunakan pengetahuan. Oleh karena itu, pembelajaran harus memberikan kesempatan kepada peserta didik untuk mengkonstruksi pengetahuan dalam proses kognitifnya. Supaya benar-benar memahami dan dapat menerapkan pengetahuan, peserta didik perlu didorong untuk bekerja memecahkan masalah, menemukan sesuatu untuk dirinya, dan berupaya keras mewujudkan ide-idenya.

Selama ini, guru belum banyak menumbuhkan pendidikan karakter kepada siswa, sehingga banyak siswa yang belum menyadari karakter yang seharusnya terbentuk, mereka lebih suka mencontek atau bertanya kepada siswa lain sewaktu mengerjakan soal, takut bertanya kepada guru jika belum paham tentang materi yang diajarkan, menyepelekan tugas atau pekerjaan rumah dan banyak siswa yang berbicara dengan teman-temannya selama proses pembelajaran berlangsung. Oleh karena itu, pendidikan karakter khususnya sikap percaya diri, kejujuran serta tanggung jawab sangat penting dalam pembelajaran matematika, sehingga dalam 
proses pembelajaran rasa percaya diri, disiplin serta tanggung jawab diharapkan dapat muncul dan dimiliki oleh setiap siswa.

Proses pembelajaran dialami sepanjang hayat seorang manusia serta dapat berlaku di manapun dan kapanpun. Dalam konteks pendidikan, guru mengajar supaya peserta didik dapat belajar dan menguasai isi pelajaran hingga mencapai sesuatu objektif yang ditentukan (aspek kognitif), juga dapat mempengaruhi perubahan sikap (aspek afektif), serta keterampilan (aspek psikomotor) peserta didik. Pengajaran memberi kesan hanya sebagai pekerjaan satu pihak, yaitu pekerjaan guru saja. Sedangkan pembelajaran juga menyiratkan adanya interaksi antara guru dengan peserta didik.

Karakter yang baik berkaitan dengan mengetahui yang baik (knowing the good), mencintai yang baik (loving the good), dan melakukan yang baik (acting the good). Ketiga ideal ini satu sama lain sangat berkaitan. Seseorang lahir dalam keadaan bodoh, dorongan-dorongan primitif yang ada dalam dirinya kemungkinan dapat memerintahkan atau menguasai akal sehatnya. Maka, efek yang mengiringi pola pengasuhan dan pendidikan seseorang akan dapat mengarahkan kecenderungan, perasaan, dan nafsu besar menjadi beriringan secara harmoni atas bimbingan akal dan juga ajaran agama (Sudrajat, 2011).

Dengan demikian dapat disimpulkan bahwa karakter siswa adalah kualitas mental atau kekuatan moral, akhlak atau budi pekerti siswa yang merupakan kepribadian khusus yang harus melekat pada siswa dan yang menjadi pendorong dan penggerak dalam melakukan sesuatu. Seseorang dapat dikatakan berkarakter jika telah berhasil menyerap nilai dan keyakinan yang dikehendaki masyarakat serta digunakan sebagai kekuatan moral dalam hidupnya. Karakter siswa mengacu pada serangkaian sikap, perilaku, motivasi, dan keterampilan.

Pendidikan karakter memiliki makna lebih tinggi dari pendidikan moral karena pendidikan karakter tidak hanya berkaitan dengan benar atau salah, akan tetapi bagaimana menanamkan kebiasaan tentang hal - hal yang baik dalam kehidupan sehingga anak memiliki kesadaran dan pemahaman yang tinggi serta kepedulian dan komitmen untuk menetapkan kebajikan dalam kehidupan seharihari.

Nilai-nilai karakter yang dikembangkan dalam pembelajaran matematika tetap harus berlandaskan pada nilai-nilai universal. Melalui kegiatan pembelajaran ini, guru dapat mengembangkan nilai-nilai karakter seperti jujur, demokrasi, mandiri, kerja keras, kreatif, rasa ingin tahu, dan sebagainya. Di sini peneliti hanya meneliti karakter yang dapat diterapkan pada pembelajaran matematika, yang biasanya terdapat pada silabus dan RPP guru.

Berbagai upaya dapat dilakukan oleh guru matematika untuk mengembangkan nilai-nilai karakter tersebut. Guru harus bisa menciptakan suasana belajar yang mendukung terlaksananya pendidikan karakter, salah satunya adalah pembelajarana siswa aktif. Melalui pembelajaran siswa yang aktif diharapkan berkembangnya nilai -nilai karakter seperti disiplin, tanggung jawab, rasa ingin tahu, kreatif dan lain-lain. Penanaman karakter ini dilakukan secara terus menerus sehingga diharapkan menjadi suatu kebiasaan. 


\section{METODE PENELITIAN}

Penelitian ini merupakan penelitian deskriptif dengan pendekatan kualitatif. Subjek penelitian ini adalah guru matematika di SMP Negeri 5 Mandai sebanyak 2 orang dengan pertimbangan kriteria atau ciri-ciri tertentu yang diterapkan berdasarkan fokus penelitian dan tujuan penelitian. Adapun langkahlangkah penentuan subjek pada penelitian ini yaitu: 1) Guru yang mengajar pelajaran matematika di kelas VII dengan menggunakan kurikulum 2013 di SMP Negeri 5 Mandai. 2) Guru yang menerapkan pendidikan karakter dalam pembelajaran matematika yakni karakter disiplin, jujur, demokratis, kerja keras dan teliti, kreatif, rasa ingin tahu, mandiri, serta tanggung yang ditunjukkan melalui perangkat pembelajaran berbasis karakter. 3) Berdasarkan rekomendasi dari kepala sekolah atau wakasek kurikulum di SMP Negeri 5 Mandai. Instrument yang digunakan dalam penelitian ini terdiri dari peneliti sendiri, pedoman wawancara dan pedoman observasi. Data yang dikumpulkan dalam penelitian yaitu data observasi, wawancara dan dokumentasi.

\section{HASIL PENELITIAN DAN PEMBAHASAN}

Berdasarkan pada hasil observasi awal yang telah dilakukan, diperoleh bahwa guru matematika di kelas VII.c dan kelas VII.e di SMP Negeri 5 Mandai Kabupaten Maros telah melaksanakan pendidikan karakter dalam pembelajaran matematika. Pembelajaran tersebut telah berlangsung sebelum diberlakukannya Kurikulum 2013 yang memang telah dikenal dengan kurikulum pendidikan karakter. Dalam segi persiapan guru telah bersama-sama mengembangkan silabus dan RPP yang memuat nilai-nilai karakter.

Hasil analisis dokumen silabus yang disusun guru matematika SMP Negeri 5 Mandai Kabupaten Maros dikembangkan dengan komponen kompetenasi dasar, materi pokok, nilai karakter, kegiatan pembelajaran, penilaian, alokasi waktu, dan sumber belajar . Adapun nilai karakter yang terdapat pada silabus yaitu religius, kerja keras, mandiri, tanggung jawab dan kreatif. Sedangkan menurut kemendiknas ada 18 nilai karakter yang dapat dikembangkan, dan dalam dokumen silabus guru peneliti hanya melihat 5 nilai karakter yang ingin dikembangkan.

Hasil analisis RPP yang telah disusun oleh guru matematika di SMP Negeri 5 Mandai Kabupaten Maros yaitu dalam penyusunan RPP guru matematika SMP Negeri 5 mandai berisi kompetensi inti (KI-1, KI-2, KI-3, KI-4), kompetensi dasar dan indikator pencapaian, nilai karakter, tujuan pembelajaran (pertemuan $7,8,9,10,11$ ), materi pembelajaran (materi pembelajaran regular, pengayaan, dan remedial), metode pembelajaran, media dan bahan, sumber belajar, langkah-langkah pembelajaran (kegiatan pendahuluan, inti dan penutup), serta penilaian (kompetensi aspek siswa dan pengetahuan).

Berdasarkan hasil dokumentasi, hasil pengamatan, dan hasil wawancara terhadap subjek RY dan NI selaku subjek yang mengembangkan nilai-nilai karakter dalam proses pembelajaran matematika, diketahui bahwa: 1) Subjek telah mengembangkan nilai-nilai karakter yang ada pada silabus ke RPP yang telah dibuat. 2) Subjek telah mengembangkan nilai-nilai karakter yang ada pada RPP dalam proses pembelajaran matematika. 
Pelaksanaan pendidikan karakter yang dilakukan dalam proses pembelajaran matematika di kelas dilakukan oleh guru yang terlihat pada kegiatan guru seperti kegiatan pendahuluan, kegiatan inti, dan kegiatan penutup. Berdasarkan lembar observasi kegiatan pendahuluan yang dilakukan dengan mempersiapkan peserta didik untuk mengikuti proses pembelajaran seperti mengajak siswa berdoa, mengabsen siswa, mengajukan pertanyaan-pertanyaan tentang materi yang sudah dipelajari dan terkait dengan materi yang akan dipelajari, mengantarkan peserta didik kepada suatu permasalahan atau tugas yang akan dilakukan untuk mempelajari suatu materi dan menjelaskan tujuan pembelajaran atau KD yang akan dicapai dan menyampaikan garis besar cakupan materi dan penjelasan tentang kegiatan yang akan dilakukan peserta didik untuk menyelesaikan permasalahan atau tugas.

Kegiatan inti merupakan proses untuk mencapai tujuan pembelajaran yang dilakukan secara interaktif, inspiratif, menyenangkan, menantang dan memotivasi siswa untuk aktif dalam proses pembelajaran dengan mengerjakan soal secara individu maupun kelompok. Sedangkan kegiatan penutup, biasanya guru bersama siswa membuat rangkuman pelajaran, melakukan umpan balik dan menyampaikan rencana pembelajaran pada pertemuan berikutnya.

Berdasarkan hasil observasi dan hasil wawancara terhadap subjek yang mengembangkan nilai-nilai karakter dalam proses pembelajaran matematika, diketahui bahwa: 1) Guru telah mengembangkan nilai karakter disiplin, religius, jujur, kerja keras, mandiri, demokratis, teliti, kreatif, tanggung jawab dan rasa ingin tahu dalam proses pembelajaran matematika. 2) Aktivitas-aktivitas guru dalam mengembangkan nilai-nilai karakter dalam dalam proses pembelajaran matematika. 3) Guru telah melakukan kegiatan evaluasi dalam proses pembelajaran matematika. 4) Ditinjau dari segi evaluasi dalam proses pembelajaran matematika yang berdampak pada pembentukan karakter siswa yaitu melalui kompetensi aspek sikap siswa, aspek pengetahuan seperti pemberian ulangan harian, dan keterampilan. Kemajuan siswa dapat diketahui oleh guru dan orang tua, bahkan oleh siswa sendiri. 5) Guru melakukan evaluasi kepada siswa, kapan saja baik selama proses pembelajaran matematika maupun saat di luar jam pelajaran.

Hasil penelitian ini sesuai dengan penelitian yang telah dilakukan oleh (Pertiwi \& Marsigit, 2017) menyatakan bahwa implementasi pendidikan karakter dalam pembelajaran matematika meliputi perencanaan, pelaksanaan dan penilaian. Perencanaan berkaitan dengan implementasi pendidikan karakter meliputi kegiatan guru dalam menyusun perangkat pembelajaran, pengembangan silabus, dan pengembangan Rencana Pelaksanaan Pembel-ajaran (RPP) bermuatan nilainilai karakter. Pendidikan karakter dalam perencanaan pembel-ajaran matematika terdiri atas dua indikator yaitu: (1) membuat silabus bermuatan nilai-nilai karakter sebagai acuan dalam pengembangan RPP, dan (2) membuat RPP bermuatan nilainilai karakter sebagai pedoman pembelajaran yang memenuhi standar proses.

Sejalan dengan penelitian (Wahyudin, 2013) berpendapat bahwa pengintegrasian karakter/sikap dalam pembelajaran pada mata pelajaran dapat 
dijelaskan dengan alur pengembangan sebagai berikut. Proses perancangan dan pembelajaran dimulai dari KI-3 (pengetahuan) ke KI-4 (keterampilan) dan selanjutnya memberikan dampak terhadap terbentuknya kompetensi dasar pada KI-2 (sikap sosial) dan KI-1 (sikap spiritual). Pada proses perancangan, setelah KI-3 dan KI 4-tuntas dianalisis, selanjutnya menurunkan materi yang relevan beserta rancangan skenario pembelajarannya, termasuk penugasan dan penilaian. Berdasarkan aktivitas belajar dan penugasan tersebut, dirancang indikator KD pada KI-1 dan KI-2 dengan cara diintegrasikan. Urutan perancangan dan pelaksanaan pembelajaran mulai dari KI-3 menuju KI-4 menunjukkan bahwa keterampilan hanya dapat dibangun dengan hasil yang baik melalui pengetahuan. Keterampilan yang tidak melalui proses pengetahuan tampaknya belum menghasilkan karya yang baik. Dalam proses pemerolehan pengetahuan dan keterampilan inilah sikap diintegrasikan dalam suatu mata pelajaran, dan akhirnya seluruh mata pelajaran, berkontribusi terhadap pembentukan sikap.

Walaupun dari hasil penelitian yang telah dilakukan menunjukkan adanya perbedaan antara isi RPP dan kenyataan di lapangan, namun subjek sebagai praktisi pendidikan telah melaksanakan penerapan pendidikan karakter dengan memasukkan nilai-nilai karakter pada RPP. Kemudian biasanya subjek dalam mengajar menyesuaikan dengan kondisi kelas yang dihadapi.

Menurut hasil penelitian (Jaeng, 2016) bahwa kecerdasan merupakan pengintegrasian semua kecakapan pengetahuan, keterampilan, dan sikap. Karakter cerdas terintegrasi dalam pendidikan matematika, melalui pelatihan peserta didik untuk selalu membangkitkan rasa ingin tahu perkembangan matematika, tentu ke perkembangan ilmu pengetahuan pada umumnya. Karakter peduli terintegrasi dalam pembelajaran/ pendidikan matematika, melalui pembelajaran matematika dengan model Pembelajaran Perseorangan dan Kelompok Kecil (Model PPKK). Karakter tangguh terintegrasi dalam pendidikan matematika, melalui kebiasaan menghadapi dan memecahkan masalah/soal matematika yang kompleks dengan tekun, dan senang. Kebiasaan ini dapat diterapkan dalam kehidupan peserta didik. Karakter tertib/disiplin terintegrasi dalam pendidikan matematika, melalui pembiasaan peserta didik untuk tertib/ disiplin mengerjakan tugas-tugas matematika, baik tugas perseorangan maupun tugas kelompok. Tugas-tugas diselesaikan dengan teliti, cermat, dan tepat waktu. Kebiasaan tertib/ disiplin ini akan terbawa ke kehidupan peserta didik.

Bagi anak yang berprestasi mendapatkan penghargaan minimal tepuk tangan dan memotivasi agar lebih ditingkatkan. Selain evaluasi dengan ulangan harian, juga evaluasi dari nilai tugas baik individu maupun kelompok, dan nilai sikap siswa baik di kelas maupun di lingkungan sekolah bagaimana sikap siswa berinteraksi dengan orang lain. Subjek dapat memberi sanksi bagi siswa yang melanggar aturan kelas maupun aturan sekolah yang telah ditetapkan.

Sejalan dengan penelitian (Bilda, 2016) menyatakan bahwa pembelajaran matematika sejauh ini lebih menekankan kepada capaian kognitif peserta didik, dimana peserta didik dikenalkan rumus-rumus dan sebatas penerapan pada konsep abstrak. Walaupun sebenarnya telah ada pembenahan kurikulum yang menilai kemampuan peserta didik tidak hanya pada aspek kognitifnya, melainkan dilihat juga pada aspek afektif (sikap) dan psikomotorik (skill). Pada kenyataannya, 
ketiga aspek tersebut dirasa kurang efisien diterapkan pada pembelajaran, hal ini dilatarbelakangi oleh kurangnya kesadaran diri dari pelaku pendidikan untuk menanamkan pendidikan karakter yang telah menjadi tujuan pendidikan bangsa. Setiap kegiatan pembelajaran, sudah seharusnya mempunyai rancangan pembelajaran yang terencana dan terstruktur sebelum kegiatan pembelajaran di kelas dilaksanakan, yang dikenal dengan Rencana Pelaksanaan Pembelajaran atau RPP. Agar tidak lari dari pencapaian aspek selain aspek kognitif, perlu pembaharuan pada rencana pelaksanaan pembelajaran tersebut yakni perlu ditambahkannya secara tertulis guna pembentukan pendidikan karakter pada indikator pembelajaran, tujuan pembelajaran, metode pembelajaran, kegiatan pembelajaran serta penilainnya. Tentunya pembaharuan ini tidak terlepas dari pandangan pelaku pendidikan kepada aspek kognitif peserta didik.

\section{SIMPULAN DAN SARAN}

Berdasarkan hasil analisis data penelitian serta pembahasan yang telah diuraikan maka dapat ditarik kesimpulan sebagai berikut: 1) Aktivitas-aktivitas guru ditinjau dari segi persiapan dalam proses pembelajaran matematika yang berdampak pada pembentukan karakter siswa dapat dilihat dalam penyusunan silabus dan RPP guru. Silabus mempunyai nilai karakter siswa yang akan diterapkan pada pembelajaran matematika yaitu religius, tanggung jawab, kreatif, teliti, dan mandiri. Nilai-nilai karakter yang terdapat pada silabus dikembangkan saat penyusunan RPP sehingga nilai-nilai karakter yang diterapkan bertambah yakni religius, tanggung jawab, kreatif, teliti, kejujuran, disiplin,kerja keras, rasa ingin tahu, dan mandiri. 2) Aktivitas-aktivitas guru ditinjau dari segi pelaksanaan dalam proses pembelajaran matematika yang berdampak pada pembentukan karakter siswa yaitu guru menerapkan pendidikan karakter mulai dari kegiatan pendahuluan, kegiatan inti dan kegiatan penutup. Nilai-nilai karakter pada kegiatan pendahuluan yaitu tanggung jawab, religius, disiplin dan kejujuran. Nilai karakter yang diterapkan dalam kegiatan inti meliputi nilai tanggung jawab, kerja keras, rasa ingin tahu, teliti, demokrasi, dan kreatif. Sedangkan nilai-nilai karakter yang diterapkan pada kegiatan penutup yaitu nilai teliti, kerja keras, rasa ingin tahu dan religius. 3) Aktivitas-aktivitas guru ditinjau dari segi evaluasi dalam proses pembelajaran matematika yang berdampak pada pembentukan karakter siswa melalui kompetensi aspek sikap siswa, aspek pengetahuan seperti pemberian ulangan harian, dan keterampilan. Kemajuan siswa dapat diketahui oleh guru dan orang tua, bahkan oleh siswa sendiri. Evaluasi pembelajaran matematika berkarakter di SMP Negeri 5 Mandai Kabupaten Maros dilaksanakan secara terpadu dengan kegiatan belajar mengajar (KBM). Peranan guru dalam pendidikan karakter adalah mengembangkan nilai-nilai karakter di sela-sela proses pembelajaran matematika yang dimulai dari pendahuluan, kegiatan inti, kegiatan akhir serta evaluasi dalam pembelajaran. Pendidik berkewajiban memberi teladan kepada peserta didik yang tumbuh dan berkembang di sekolah, di rumah maupun dimasyarakat. 


\section{DAFTAR PUSTAKA}

Bilda, W. (2016). Pendidikan Karakter Terencana Melalui Pembelajaran Matematika. Journal of Mathematics Education, 8.

Harun, C. Z. (2013). Manajemen Pendidikan Karakter. Jurnal Pendidikan Karakter, (3).

Haryati, S. (2017). Pendidikan Karakter dalam Kurikulum 2013. Tersedia Secara Online Di: Http://Lib. Untidar. Ac. Id/Wp-Content/Uploads [Diakses Di Bandung, Indonesia: 17 Maret 2017].

Jaeng, M. (2016). Pendidikan Karakter Melalui Pendidikan Matematika. Universitas Tadulako, 5, 167.

Ma'unah. (2014). Analisis Penerapan Pendidikan Karakter Pada Pembelajaran Matematika Dalam Kurikulum Tingkat Satuan Pendidikan (Siswa Kelas VIII B Dan VIII C SMP Muhammadiyah 10 Surakarta Tahun 2013/2014). Universitas Muhammadiyah Surakarta, Surakarta.

Pertiwi, I., \& Marsigit, M. (2017). Implementasi pendidikan karakter dalam pembelajaran matematika SMP di Kota Yogyakarta. Jurnal Riset $\begin{array}{lll}\text { Pendidikan Matematika, } & \text { 4(2), }\end{array}$ https://doi.org/10.21831/jrpm.v4i2.11241

Setyowati, E. (2015). Penerapan Kurikulum 2013 Dalam Penanaman Karakter Siswa Pada Pembelajaran Matematika (Studi Kasus di SMP Al-Irsyad Surakarta tahun 2013/2014). Universitas Muhammadiyah Surakarta, Surakarta.

Sudrajat, A. (2011). Mengapa Pendidikan Karakter? Jurnal Pendidikan Karakter, $1(1)$.

Wahyudin. (2013). Membangun Karakter Bangsa Melalui Pembelajaran Matematika Kurikulum 2013. Jurnal Pendidikan, 14. Retrieved from http://jurnal.ut.ac.id/index.php/JP/article/view/171/136 